\title{
AGROEKOSISTEM PERTANAMAN JAGUNG DI DESA SASA PROVINSI MALUKU UTARA
}

\author{
Lidya M. Ivakdalam \\ Staf Pengajar FAPERTA UMMU-Ternate, $\boldsymbol{e}$-mail: -
}

\begin{abstract}
ABSTRAK
Peningkatan produksi jagung dipengaruhi oleh beberapa kendala salah satunya adalah kendala abiotik dan biotik. Kendala abiotik disebabkan oleh rendahnya ketersediaan hara di tanah, sementara kendala biotik meliputi gangguan yang disebabkan oleh organisme pengganggu tanaman (OPT). Masalah OPT (hama dan penyakit) inilah yang membuat petani selalu kesulitan dan memilih mengunakan pestisida sebagai jalan keluarnya. Sementara dampak negatif dari penggunaan pestisida kimia selalu muncul terutama karena penggunaan yang tidak bijaksana. Akibatnya terjadi resistensi, resurjensi, terbunuhnya musuh alami dan menimbulkan pencemaran lingkungan, karena kadar residu pestisida kimia dapat meningkat dan membunuh organisme yang ada pada rantai makanan Untung (2006). Penelitian ini bertujuan mempelajari kelimpahan Artropoda pada agroekosistem jagung dan pengelompokkan berdasarkan perannya. Penelitian berlangsung pada November 2010. Hasil penelitian menunjukkan bahwa keragaman Artropoda pada agroekosistem jagung ditemukan lima kelompok Artropoda yaitu hama, predator, parasitoid, serangga netral, dan dekomposer. Kelompok hama memiliki kelimpahan lebih banyak dibandingkan kelompok lainnya, dengan pola sebaran hama $H$. armigera dan O. furnacalis bersifat acak, dan $R$. maidis bersifat mengelompok.
\end{abstract}

Kata Kunci: PHT, Jagung

\section{PENDAHULUAN}

\subsection{Latar Belakang}

Kebutuhan jagung di Indonesia saat ini cukup besar, dimana pada tahun 2004 kebutuhan jagung lebih dari 10 juta ton pipilan kering per tahun. Konsumsi jagung terbesar adalah untuk pangan dan industry pakan ternak, seperti berkembangnya produk pangan jagung dalam bentuk tepung jagung dan sebanyak $51 \%$ bahan baku pakan ternak dari jagung. Pemerintah telah mencanangkan swasembada tiga komoditas pangan, yang diharapkan dapat terwujud hingga tahun 2015. Ketiga komoditas tersebut adalah padi, jagung, dan kedelai.

Swastika et al. (2004) melaporkan bahwa kendala yang sering dihadapi dalam peningkatan produksi jagung adalah (1) 23rgani ekonomi yang mencakup mahalnya input (benih dan pupuk), rendahnya harga output (hasil), infrastruktur yang sedikit dan rendahnya daya beli; (2) rendahnya adopsi teknologi dan lemahnya 23rgani pemasaran yang terindikasi dari sulitnya mendapatkan kredit dan pasar; (3) rendahnya kesuburan tanah, sekitar $89 \%$ tanaman jagung di Indonesia diusahakan di lahan kering dengan tingkat kesuburan yang rendah; dan (4) kendala abiotik dan 23rgani. Kendala abiotik disebabkan oleh rendahnya ketersediaan hara di tanah, sementara kendala 23rgani meliputi gangguan yang disebabkan oleh 23rganism pengganggu tanaman (OPT).

Masalah hama dan penyakit inilah yang membuat petani selalu kesulitan dan memilih mengunakan pestisida sebagai jalan keluarnya. Sementara dampak negatif dari penggunaan pestisida kimia selalu muncul terutama karena penggunaan yang tidak bijaksana. Akibatnya terjadi resistensi, resurjensi, terbunuhnya musuh alami dan menimbulkan pencemaran lingkungan. Menurut Untung (2006) kadar residu pestisida kimia dapat meningkat dan membunuh organisme yang ada pada rantai makanan.

Tingginya keanekaragaman pada suatu ekosistem, umumnya terdapat rantai makanan yang lebih panjang dan lebih kompleks, sehingga lebih banyak terjadi interaksi pemangsaan, 
parasitisme, kompetisi, komensalisme, dan mutualisme. Odum (1994), menyebutkan bahwa adanya Interaksi mengakibatkan keseimbangan ekosistem tidak mudah berubah karena, ekosistem berlangsung stabil.

PHT merupakan konsep pengelolaan hama yang berwawasan ekologi atau pengendalian hama akrab lingkungan yang mendorong bekerjanya musuh alami. Cara pengendalian ini bersifat non kimia yang memanfaatkan predator dan parasitoid melalui mekanisme homeostatis mampu mempertahankan keseimbangan serangga, sehingga populasi hama tidak akan mendatangkan kerugian ekonomi bagi petani. Konsep PHT lebih menekankan pada penjagaan dan pemantapan keseimbangan ekosistem dengan mempertahankan populasi hama tetap berada di bawah ambang ekonomi maka, akan selalu mengusahakan terbentuknya agroekosistem yang memiliki keanekaragaman hayati yang tinggi sehingga terbentuk agroekosistem yang relatif stabil.

Keanekaragarnan dan kelimpahan Artropoda dalam ekosistem sangat penting manfaatnya dalam PHT. Untuk itu komposisi spesies Artropoda dan susunan rantai makanan dalam ekosistem merupakan dasar rekomendasi pengendalian hama yang ditetapkan dapat memberikan hasil yang optimal sesuai dengan prinsip-prinsip dasar PHT.

\subsection{Tujuan}

Penelitian ini bertujuan mempelajari kelimpahan Artropoda pada agroekosistem jagung dan pengelompokkan berdasarkan perannya.

\section{BAHAN DAN METODE}

\subsection{Tempat dan Waktu}

Penelitian berlangsung di kebun Jagung petani Desa Sasa Provinsi Maluku, pada bulan November 2010.

\subsection{Bahan dan Alat}

Bahan dan alat yang digunakan adalah tanaman jagung fase vegetatif dan generatif, Formalin, lubang perangkap (pitfall trap), kertas label, kantong plastik, seng penutup, dan mikroskop.

\subsection{Metode}

Teknik pengambilan sampel Artropoda yang digunakan adalah engamatan langsung dan pengambilan sampel metode nisbi dengan menggunakan alat-alat perangkap jebakan (pitfall trap).

Pitfall digunakan untuk mengumpulkan contoh Artropoda yang aktif pada permukaan tanah. Pitfall yang telah diisi larutan Formalin dipasang sehingga sejajar permukaan tanah dan diberi tutup dari seng lurus. Untuk hari-hari pengamatan Artropoda yang terperangkap dimasukkan kedalam kantung plastik untuk diidentifikasi. Jumlah pitfall yang dipasang adalah 10 buah yang tersebar secara sistematis di lahan jagung. Pengambilan contoh Artropoda dilakukan dalam empat tahap dengan interval pengambilan sampel seminggu sekali. Kemudian diklasifikasikan menurut kelompok dan fungsinya.

Pola pengambilan sampel yang digunakan adalah pola pengambilan sampel sistematis. Penentuan unit sampel dan jumlah sampel yang diamati per petak pengamatan dalam program sampling ditetapkan berdasarkan rute perjalanan pengamat yaitu pada baris tanaman. Arah perjalanan pengamat dalam melakukan pengamatan mencakup seluruh tanaman pada petak pengamatan. Penentuan jumlah sampel pada petak pengamatan;

a. Jumlah sampel yang diamati adalah 154 rumpun (22 kolom rumpun $\mathrm{x} 70$ baris rumpun $=1540$ rumpun $\mathrm{x} 10 \%=154$ rumpun)

b. Rumpun sampel yang diamati pada lahan jagung dengan mengikuti rute baris tanaman

c. Pengamatan dilakukan terhadap semua Artropoda yang terdapat pada rumpun sampel. Kemudian diklasifikasikan menurut kelompok fungsinya yaitu hama, predator, parasitoid, dan serangga netral serta setiap kelompok dihitung kelimpahannya

d. Pengambilan contoh Artropoda dilakukan dalam empat tahap dengan interval satu minggu sekali

\section{HASIL DAN PEMBAHASAN \\ 3.1. Populasi Artropoda Pengamatan Langsung}

Komunitas Artropoda yang dijumpai adalah kelompok hama $(89,56 \%)$, parasitoid $(0,54 \%)$, predator $(8,82 \%)$, dan serangga netral $(1,07 \%)$. Kelompok hama merupakan contoh Artropoda yang paling dominan dijumpai, hama yang dominan dijumpai adalah Ostrinia furnacalis, Helicoperva zea, $R$. maidis, dan Empoasca sp. Hama $R$. maidis memiliki kelimpahan paling tinggi sebesar 82,33\% dibandingkan hama lainnya. Parasitoid memiliki kelimpahan lebih rendah dibanding Artropoda 
lainnya. Parasitoid yang dijumpai adalah Ordo Hymenoptera Braconidae dan Ichneumonidae) dan Diptera (Tachinidae). Kelompok predator yang dominan adalah Famili Coccinellidae, kumbang Menochilus sexmaculatus dengan kelimpahan mencapai $(4,44 \%)$ dan Scymnus sp. $(0,84 \%)$. Kelimpahan populasi serangga netral mencapai 1,07\% (Tabel 1).

Tabel 1. Artropoda pada agroekosistem jagung pada pengamatan langsung

\begin{tabular}{|c|c|c|c|}
\hline \multicolumn{3}{|c|}{ Artropoda } & \multirow{2}{*}{$\begin{array}{c}\text { Kelimpahan relatif (\%) } \\
\quad(n=10.165)\end{array}$} \\
\hline Ordo & Famili & Morfospesies & \\
\hline \multicolumn{3}{|l|}{ Hama } & 89,56 \\
\hline \multirow[t]{2}{*}{ Lepidoptera } & Pyraustinae & Ostrinia furnacalis & 0,79 \\
\hline & Noctuidae & Helicoperva zea & 1,94 \\
\hline \multirow[t]{3}{*}{ Hemiptera } & Alydidae & Leptocorisa sp. & 0,15 \\
\hline & Pentatomidae & Nezara viridula & 0,22 \\
\hline & Cicadellidae & Empoasca sp. & 4,14 \\
\hline Homoptera & Aphididae & R. maidis & 82,33 \\
\hline \multicolumn{3}{|l|}{ Parasitoid } & 0,54 \\
\hline \multirow[t]{2}{*}{ Hymenoptera } & Braconidae & Braconidae morfospesies 01 & 0,18 \\
\hline & Ichneumonidae & Icheumonidae morfospesies 01 & 0,21 \\
\hline Diptera & Tachinidae & Compsilura concinnata & 0,16 \\
\hline \multicolumn{3}{|l|}{ Predator } & 8,82 \\
\hline \multirow[t]{3}{*}{ Coleoptera } & Coccinellidae & Menochilus sexmaculatus & 4,44 \\
\hline & & Scymnus sp. & 0,84 \\
\hline & Staphylinidae & Paederus fuscipes & 3,55 \\
\hline \multicolumn{3}{|l|}{ Serangga netral } & 1,07 \\
\hline \multirow[t]{3}{*}{ Lepidoptera } & Hesperidae & Hesperidae morfospesies 01 & 0,26 \\
\hline & Pieridae & Pieridae morfospesies 01 & 0,06 \\
\hline & Nymphalidae & Nymphalidae morfospesies 01 & 0,13 \\
\hline Hymenoptera & Apidae & Apidae morfospesies 01 & 0,61 \\
\hline Mecoptera & $\begin{array}{l}\text { Mecoptera morfofamili } \\
01\end{array}$ & Mecoptera morfospesies 01 & 0,02 \\
\hline
\end{tabular}

Secara keseluruhan kelimpahan populasi hama lebih besar dibandingkan kelimpahan Artropoda lainnya. Hama-hama utama yang dijumpai adalah penggerek batang $(O$. furnacalis), penggerek tongkol $(H$. zea), wereng daun (Empoasca sp.), dan kutudaun ( $R$. maidis). Pada minggu pertama populasi hama masih dominan dijumpai pada hama $O$. furcinalis. Pada minggu ketiga dan keempat terjadi peningkatkan populasi hama kutudaun yang diikuti oleh peningkatan populasi predator Coccinellidae dan Staphylinidae. Hama kutudaun ( $R$. maidis) merupakan hama dengan kelimpahan paling tinggi pada agroekosistem jagung dibandingkan hama lainnya. Peningkatan populasi kutudaun tidak dibatasi oleh takson inang, melainkan tempat awal kutudaun hidup dan membentuk koloni. Tanaman atau tumbuhan berstatus inang bagi kutudaun apabila dapat menunjang kehidupan dan perkembangan kutudaun. Hal ini ditunjukkan oleh dapat terbentuknya koloni kutudaun pada tanaman atau tumbuhan dimaksud.

\subsection{Populasi Artropoda Metode Pitfall}

Komunitas Artropoda penghuni permukaan tanah yang dijumpai adalah hama $(1,83 \%)$, predator $(32,38 \%)$, dekomposer $(62,46 \%)$, dan serangga netral $(3,34 \%)$. Hasil identifikasi dapat diketahui bahwa Artropoda yang paling dominan dijumpai pada permukaan tanah adalah Collembola (60,57\%). Serangga dekomposer lainnya adalah Blattodea $(1,89 \%)$ yang menempati proporsi sangat kecil dari komunitas dekomposer. Kelompok predator yang dijumpai adalah Famili Formicidae $(14,93 \%)$, Staphylinidae $(2,09 \%)$, Carabidae $(4,96 \%)$, Linyphiidae $(1,57 \%)$, Oxyopidae $(0,87 \%)$, Spongiphoridae $(0,78 \%)$, Gryllidae $(1,74 \%)$, dan Forficulidae $(5,44 \%)$. Kelompok hama terdiri atas Famili Coreidae $(0,78 \%)$, dan Gryllotalpidae (1,04\%) (Tabel 2). 
Tabel 2. Artropoda permukaan tanah pada agroekosistem jagung

\begin{tabular}{|c|c|c|c|}
\hline \multicolumn{3}{|c|}{ Artropoda } & \multirow{2}{*}{$\begin{array}{c}\text { Kelimpahan relatif (\%) } \\
(n=383)\end{array}$} \\
\hline Ordo & Famili & Morfospesies & \\
\hline Hama & & & 1,83 \\
\hline Orthoptera & Gryllotalpidae & Gryllotalpa sp. & 1,04 \\
\hline Hemiptera & Coreidae & Coreidae morfospesies 01 & 0,78 \\
\hline Predator & & & 32,38 \\
\hline \multirow[t]{2}{*}{ Hymenoptera } & Formicidae & Myrmecia nigriceps & 7,00 \\
\hline & Formicidae & Solenopsis germinata & 7,93 \\
\hline \multirow[t]{2}{*}{ Dermaptera } & Forficulidae & Elaunon bipartitus & 5,44 \\
\hline & Spongiphoridae & Chaetospinia brunneri & 0,78 \\
\hline \multirow[t]{2}{*}{ Coleoptera } & Carabidae & Chlaenius spp. & 4,96 \\
\hline & Staphylinidae & Paederus fuscipes & 2,09 \\
\hline \multirow[t]{2}{*}{ Aranea } & Linyphiidae & Atypena formosana & 1,57 \\
\hline & Oxyopidae & Oxyopes javanus & 0,87 \\
\hline Orthoptera & Gryllidae & Gryllacris signifera & 1,74 \\
\hline Dekomposer & & & 62,46 \\
\hline Collembola & Isotomidae & Isotomidae morfospesies 01 & 60,57 \\
\hline Blattodea & Blaberidae & Laxta irrorata & 1,89 \\
\hline Serangga netral & & & 3,34 \\
\hline \multirow[t]{2}{*}{ Coleoptera } & Tenebrionoidae & $\begin{array}{l}\text { Tenebrionoidae morfospesies } \\
01\end{array}$ & 2,41 \\
\hline & Scarabaeidae & Anomala pallida & 0,93 \\
\hline
\end{tabular}

Kelimpahan Artropoda permukaan tanah yang dijumpai menunjukkan perbedaan, Collembola menempati proporsi yang tinggi dibandingkan dengan jenis lainnya. Collembola merupakan Artropoda tanah yang paling melimpah baik jumlah maupun keanekaragamannya serta memiliki penyebaran yang luas (Russell 1988). Collembola menyukai habitat permukaan tanah yang banyak mengandung serasah dari jatuhan daun, ranting serta bagian tumbuhan lainnya (Takeda 1991). Populasi Collembola sebagai dekomposer mengalami penurunan disebabkan adanya aplikasi insektisida. Hymenoptera merupakan Artropoda tanah yang juga banyak dijumpai pada agroekosistem jagung, umumnya berasal dari Famili Formicidae. Famili Formicidae banyak terperangkap pada lubang perangkap berkaitan dengan berkurangnya tingkat kelembapan permukaan tanah sehingga banyak semut berkolonisasi di pertanaman jagung. Kumbang Carabidae hasil tangkapan lubang perangkap adalah Chlaenius sp. yang dikenal sebagai predator Artropoda bertubuh lunak seperti larva (Lovei \& Sunderland 1996), yang memangsa cacing. Beberapa jenis yang ditemukan dari
Famili Coreidae, Gryllotalpidae, dan Lygaeidae, namun kelimpahan masing rendah dibandingkan jenis Artropoda lainnya.

\subsection{Kelimpahan Artropoda Tanah}

Perbedaan jumlah spesies dan kelimpahan Artropoda tanah pada setiap agroekosistem berpengaruh juga pada perbedaan keanekaragaman spesies. Semakin tinggi keanekaragaman spesies dalam agroekosistem maka semakin tinggi indeks keanekaragamannya dan kondisi ekosistem semakin stabil yang akhirnya tercapai keseimbangan. Agrekosistem bersifat kurang stabil dicirikan oleh keanekaragaman hayati rendah. Kestabilan agroekosistem dapat dicapai dengan cara peningkatan dan memantapkan keanekaragaman hayati pada ekosistem melalui pengelolaan ekosistem antara lain mendayagunakan teknik budidaya dan meningkatkan peranan musuh alami.

Perbedaan keanekaragaman spesies Artropoda juga berhubungan dengan distribusi Artropoda tanah. Distribusi Artropoda tanah terutama dipengaruhi oleh kelembapan tanah, ketersediaan makanan, struktur tanah, dan $\mathrm{pH}$ 
tanah (Sebayang et al. 2001). Rendahnya nilai keanekaragaman Artropoda tanah dapat menggambarkan bahwa tingkat kesuburan tanah gambut pada areal penelitian dalam keadaan sedang. Proses dekomposisi atau penguraian bahan organik yang terjadi berlangsung secara sedang, dimana lebih banyak terjadi secara anaerobik oleh kelompok bakteri.

Kelimpahan spesies Artropoda pada agroekosistem jagung lebih rendah dibandingkan agroekosistem lainnya. Kelimpahan spesies yang rendah terjadi karena aplikasi insektisida oleh petani setempat yang mempengaruhi populasi Artropoda. Kelimpahan yang rendah menyebabkan tingginya nilai indeks keanekaragaman. Collembola, Arenea, dan Formicidae merupakan Artropoda yang dominan pada habitat tanah. Collembola menyukai habitat dalam tanah yang banyak mengandung bahan organik, sedangkan Arenea, dan Formicidae umumnya bertindak sebagai pemangsa kelompok serangga lainnya.

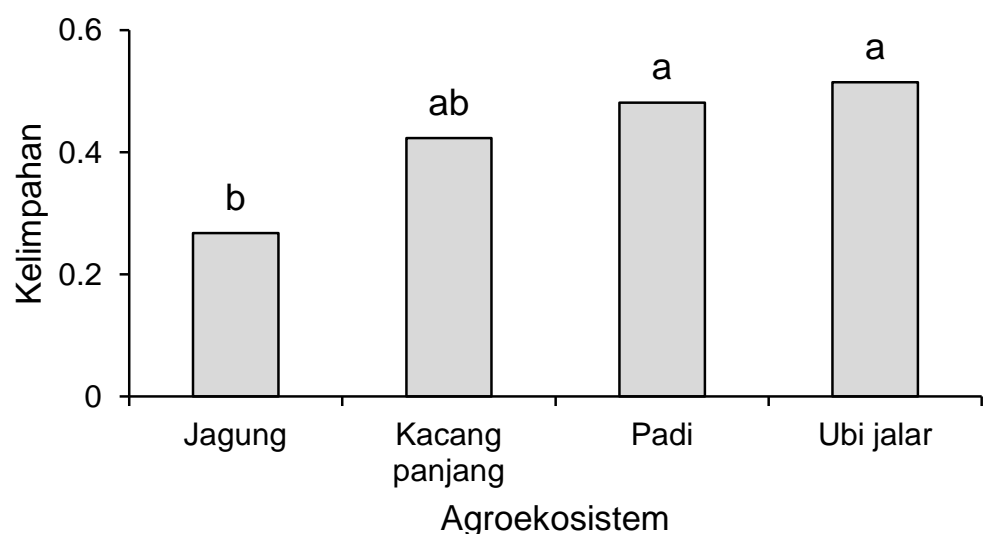

Grafik 1. Kelimpahan Artropoda tanah pada berbagai agroekosistem

Ekosistem pertanian selalu dinamis karena terus menerus mendapat perlakuan, baik yang alami maupun yang diberikan oleh manusia. Biota di dalam tanah akan mengalami perubahan sebagai perlakuan yang diberikan ke dalam tanah. Pemantauan terhadap perubahan yang terjadi memerlukan informasi awal. Pada tahap permulaan, yang diperlukan adalah pengetahuan mengenai peran Artropoda tanah dalam lingkup ekosistem pertanian. Rahmawaty et al. (2001) menyatakan bahwa Artropoda tanah memiliki peran dalam ekosistem pertanian seperti pelaku perombakan, pengatur perombakan dan pemencaran mikroba, transfer energi dan pengaliran mineral, pengendali komunitas dan populasi mikroflora, bioindikator, peningkatan porositas dan aerasi tanah, hama pertanian, serta peran dalam berfungsinya ekosistem.

\subsection{Hubungan antara Hama, Musuh Alami, Dekomposer, dan Serangga Netral pada Agroekosistem Jagung}

Secara alami terjadi interaksi antara semua komponen dalam ekosistem sehingga membentuk susunan jaring-jaring makanan, yang masingmasing kelompoknya saling memerlukan untuk kelangsungan hidupnya. Musuh alami seperti parasitoid dan predator sebagai faktor pengatur populasi di ekosistem merupakan faktor biotik yang mempunyai peran paling besar dalam menjaga keseimbangan ekosistem. Musuh alami sebagai faktor penendali, peranannya sangat tergantung kepadatan populasi (density dependent factors) mangsa atau inang. Umumnya predator bersifat polifag, keberadaannya memerlukan dukungan pakan alternatif yang dapat dipenuhi oleh populasi serangga netral. Peranan serangga netral sangat diperlukan untuk menjaga kelestarian musuh alami supaya akhirnya tercapai keseimbangan hama dan musuh alami.

Hubungan hama-hama utama, musuh alami, dan serangga netral pada agroekosistem jagung menunjukkan suatu bentuk umum dan sederhana rantai makanan. Tanaman jagung berperan sebagai produsen dimakan konsumen tingkat pertama yaitu hama-hama utama seperti Helicoperva armigera, Ostrinia furnacalis, dan Rhopalosiphum maidis. Konsumen tingkat pertama dimakan oleh konsumen tingkta kedua yaitu musuh alami seperti parasitoid telur Trichogrammatidae, predator Menochilus sexmaculatus, Scymnus sp., dan Paederus fuscipes. Serangga netral yang hidup pada tanaman jagung dengan memakan nektar dan tepung sari dapat dijadikan sebagai pakan 
alternatif terutama bagi predator yang polifag. Pada agroekosistem jagung, serangga parasitoid yang berukuran lebih kecil dari inangnya menjadi bagian dari aliran makanan. Hal ini berarti energi (makanan) juga dialihkan dari organisme yang berukuran besar ke yang berukuran lebih kecil.

Ekosistem tanaman semusim bersifat kurang stabil yang dicirikan oleh keragaman hayati rendah. Susunan jaring-jaring makanan pada ekosistem tanaman semusim bersifat sederhana, mengakibatkan populasi hama berada dalam titik ketidak seimbangan, sehingga terjadi ledakan populasi hama. Kestabilan ekosistem pada tanaman semusim dicapai dengan cara peningkatan dan pemantapan keanekaragaman Artropoda pada ekosistem melalui pengelolaan ekosistem antara lain mendayagunakan teknik budidaya dan meningkatkan peranan musuh alami.

Teori dasar dalam pengelolaan hama adalah mempertimbangkan komponen musuh alami dalam strategi pemanfaatan dan pengembangannya. Beranekaragam dan kekompleksan suatu agen hayati sangat penting dimanfaatkan dan dikembangkan untuk mengendalikan hama secara hayati karena, konsep PHT lebih mengutamakan peran pengendalian secara hayati yang menggunakan parasitoit dan predator (musuh alami).

Secara keseluruhan populasi Artropoda dari kelompok hama lebih besar jumlahnya dibandingkan dengan kelompok lainnya, hal ini mencerminkan keadaan ekosistem tanaman jagung merupakan habitat yang baik untuk kehidupan hama. Penurunan populasi Artropoda pada minggu kedua pengamatan terjadi karena adanya aplikasi insektisida.

Penurunan populasi hama diikuti menurunnya populasi predator dan parasitoid. Namun, karena predator bersifat polifag maka populasi predator dapat bertahan meskipun populasi hama rendah. Predator dapat hidup dengan memangsa serangga netral yang populasinya cukup tinggi. Berbeda dengan parasitoid yang hanya dapat bertahan hidup dengan memakan nektar dari tanaman jagung dan tumbuhan liar lainnya. Kondisi ini sangat mendukung usaha konservasi musuh alami.

Perubahan populasi Artropoda terjadi sejalan dengan perkembangan fase tumbuh tanaman jagung sebagai habitatnya. Fluktuasi hama terjadi karena adanya interaksi hama dan musuh alami karena adaya faktor terpaut kepadatan (density dependent) dan tak terpaut kepadatan (density independent). Faktor terpaut kepadatan adalah faktor pengendali alami yang mempunyai sifat penekanan terhadap populasi yang semakin meningkat pada waktu populasi semakin tinggi dan penekanan lebih rendah pada waktu populasi semakin rendah. Faktor terpaut kepadatan seperti musuh alami, makanan, dan kompetisi. Faktor tak terpaut kepadatan merupakan faktor mortalitas yang daya penekanannya terhadap populasi organisme tidak tergantung pada kepadatan populasi organisme tetapi pada kondisi abiotik seperti cuaca (Price 1997).

\section{PENUTUP}

\subsection{Kesimpulan}

Keragaman Artropoda pada agroekosistem jagung ditemukan lima kelompok Artropoda yaitu hama, predator, parasitoid, serangga netral, dan dekomposer. Kelompok hama memiliki kelimpahan lebih banyak dibandingkan kelompok lainnya, dengan pola sebaran hama $H$. armigera dan $O$. furnacalis bersifat acak, dan $R$. maidis bersifat mengelompok.

\subsection{Saran}

Perlu mempelajari keragaman setiap Artropoda yang ada pada setiap ekosistem tanaman, guna pelaksanaan tindakan pengendalian hama dan penyakit efektif dan ramah linkungan yang dapat menguntungkan pertanian.

\section{DAFTAR PUSTAKA}

Lovei GL, Sunderland KD. 1996. Ecology and behavior of ground beetles (Coleoptera: Carabidae). Annu Rev. Entomol. 41:231-256.

Odum EP. 1994. Dasar-dasar Ekologi. Samingan T, penerjemah. Yogyakarta: Gadjah Mada University Press. Terjemahan dari Fundamental of Ecology.

Price PW. 1997. Insect Ecology. $3^{\text {th }}$ ed. New York: John Wiley \& Sons.

Rahmawaty, Kusuma C, Sudardjono YR. 2001. Keanekaragaman serangga tanah dan perannya pada komunitas Rhizophora spp. dan Ceriops tagal di hutan Taman Nasional Rawa Aopa Watumohai, Sulawesi Tenggara. Di dalam: Soenardjo E et al., editor. Keanekaragaman 
Hayati Artropoda pada Sistem Produksi Pertanian. Prosiding Simposium PEI-KEHATI; Cipayung, 16-18 Oktober 2000. Bogor: PEI. hlm 61-68.

Russell, E.W. 1978. Soil Condition and Plant Growth. London: English Language Book Society.

Sebayang D, Suryati T, Andianto. 2001. Keanekaragaman dan kelimpahan Artropoda tanah di hutan alami, hutan pinus, kebun sayur, dan lahan terbuka di Gunung Tangkubanparahu. Di dalam: Soenardjo E et al., editor. Keanekaragaman Hayati Artropoda pada Sistem Produksi Pertanian. Prosiding Simposium PEI-KEHATI; Cipayung 16-18 Oktober 2000. Bogor: PEI. hlm 75-80.

Swastika, K.S. Dewa, F. Kasim, W. Sudana, R. Hendayani, K. Suhariyanto, V. Gerpacio, and P.L. Pingali. 2004. Maize in Indonesia, Production

Systems, Constraints, and Research Priorities . CIMMYTTakeda, H. 1991. Effect of Shifting Cultivation on The Soil Meso-Fauna with Special Reference to Collembolan Population in the North East Thailand. Japan: Laboratory of Foret Ecology Kyoto University.

Untung K. 2006. Pengantar Pengendalian Hama Terpadu. Yogyakarta: Gadjah Mada University Press. 